\title{
PREVALENCE OF OPEN ANGLE GLAUCOMA IN RISK GROUPS IN SLAVONIA AND BARANYA REGION
}

\author{
Josip Barać ${ }^{1,2}$, Dubravka Biuk ${ }^{1}$, Suzana Matić ${ }^{1}$, Ivona Barać ${ }^{2}$, Goran Pelčić ${ }^{3}$ and Mario Bradvica ${ }^{1}$ \\ ${ }^{1}$ Department of Ophthalmology, Osijek University Hospital Centre, Osijek, Croatia; \\ ${ }^{2}$ School of Medicine, Josip Juraj Strossmayer University of Osijek, Osijek, Croatia; \\ ${ }^{3}$ Department of Ophthalmology, School of Medicine, University of Rijeka, Rijeka, Croatia
}

\begin{abstract}
SUMMARY - The aim of this prospective study was to detect primary open angle glaucoma (POAG) in its early stage in patients at a higher risk of its development, and to identify the risk group with the highest prevalence of POAG. The study was conducted at Department of Ophthalmology, Osijek University Hospital Centre, and included 250 patients divided into five groups, as follows: group 1, patients with diabetes type 1 and type 2; group 2, patients with arterial hypertension (blood pressure $>140 / 90 \mathrm{~mm} \mathrm{Hg}$ ); group 3, patients with positive family history of POAG; group 4, patients with myopia between -3.0 and -8.0 diopters; and group 5, control group including patients aged 40 with no risk factors for POAG development. Study results showed that distribution of glaucoma patients was not equal across the groups. The prevalence of POAG in all patients was $5.6 \%$, whereas in patients with positive family history of POAG it was $14 \%$, which was statistically significantly higher than in patients with diabetes and myopia ( $4 \%$ both), as well as in control group. The difference was greatest in comparison to control group. There was no statistically significant difference in glaucoma incidence between the group of patients with positive family history (14\%) and patients with systemic hypertension (6\%). The results obtained suggest that of all risk factors analyzed, positive family history of POAG is the most important risk factor for glaucoma development in all risk groups.

Key words: Prospective studies; Glaucoma, open-angle; Hypertension; Myopia; Glaucoma; Risk factors; Control groups
\end{abstract}

\section{Introduction}

Glaucoma is the second leading cause of blindness worldwide. Primary open angle glaucoma (POAG) affects about $2 \%$ of the world population aged 40 and older, only half of them being aware of having the disease and even less receiving appropriate therapy. It is therefore not surprising that there are about 7 million people blind on both eyes as the result of glaucoma ${ }^{1,2}$. Early detection of POAG and appropriate therapy can slow down the progression and sometimes arrest development of the disease. Thus, it is of utmost impor-

Correspondence to: Dubravka Biuk, MD, Department of Ophthalmology, Osijek University Hospital Centre, Europska avenija 14-16, HR-31000 Osijek, Croatia

E-mail:dubravka.biuk@gmail.com

Received February 2, 2017, accepted August 29, 2017 tance to define the risk factors contributing to disease development.

The best-known risk factor for glaucomatous optic neuropathy $(\mathrm{GON})$ is increase in the intraocular pressure (IOP). Apart from increased IOP, other possible risk factors are old age, family history of glaucoma, diabetes, cardiovascular diseases, systemic hypertension and hypotension, vasospastic syndromes ${ }^{3-5}$ and myopia (especially myopia of 6.0 or more diopters) $)^{6,7}$.

Taking into account the high incidence of primary glaucoma within families, it has been determined that the risk of glaucoma development is 3 to 6 times higher in first-degree relatives than in the general population. Up to the present, 17 genes have been identified that can play a significant role in glaucoma pathogenesis. The gene for POAG has been identified on chromosome 1q, where the Trabecular meshwork Induced Glucocorticoid Response protein (TIGR) gene is also 
mapped. TIGR gene mutation is responsible for increased IOP by obstruction of the aqueous humor outflow channel.

Patients with diabetes are at a moderate risk of developing POAG (about 5.5\%) ${ }^{8,9}$. The lowest positive correlation for glaucoma development was determined in patients with systemic hypertension $(3 \%)^{10,11}, \mathrm{pa}^{-}$ tients with migraine headaches and vasospasm and hypotension episodes.

Numerous studies have shown that there is a greater risk of developing glaucoma in patients with moderate to high myopia. A study carried out in Sweden on more than 32,000 patients has confirmed that myopia is a significant risk factor for glaucoma development ${ }^{12}$. Increased axial length and lesser corneal thickness in myopic patients results in decreased retinal microcirculation, which may contribute to glaucoma development.

The aims of this study were to detect POAG in its early stage in patients at a higher risk of its development and to determine the risk group with the highest incidence of glaucoma.

\section{Subjects and Methods}

The study included four risk groups with $50 \mathrm{pa}^{-}$ tients each, all of them aged over 40, and 50 patients as a control group. Group 1 included patients with diabetes type 1 and type 2 with no proliferative diabetic retinopathy; group 2 included patients with arterial hypertension but with no retinal hemorrhage or ede$\mathrm{ma}$, whereby hypertension was defined as systolic pressure of $140 \mathrm{~mm} \mathrm{Hg}$ or higher, and diastolic pressure of $90 \mathrm{~mm} \mathrm{Hg}$ or higher; group 3 included patients with a family history of POAG who had not been previously diagnosed and had not received any anti-glaucoma therapy; group 4 included patients with myopia between -3.0 and -8.0 diopters; and control group included patients aged over 40 who did not belong to any risk group for developing POAG.

This research was conducted at Department of Ophthalmology, Osijek University Hospital Centre in Osijek. The patients included in the study were referred to general ophthalmology examination by their family physicians. Central visual acuity on both eyes was better than 0.3 with or without correction in all study patients.

The sample size of 140 patients was determined to be sufficient to estimate the prevalence of glaucoma with a $95 \%$ confidence interval $(95 \% \mathrm{CI})$, assuming the prevalence rate of $10 \%$.

Exclusion criteria were as follows: patients who had already been diagnosed with glaucoma and IOP; and patients who had already received anti-glaucoma therapy.

Medical history was taken in all patients, followed by clinical examination and the following diagnostic procedures:

- central visual acuity was determined using Snellen optotypes;

- IOP was taken by the Goldmann applanation tonometer and gonioscopy with Goldmann three-mirror contact lens mounted on the HaagStreit biomicroscope;

- visual field examination applying the Octopus perimetry program G1X on the Octopus perimeter 1-2-3 and FDT perimetry (Run threshold test C 20, Humphrey systems, Zeiss);

- central corneal thickness (CCT) measurement by ultrasound pachymetry using Echographe pachymeter, model Pocket II, Quantal medica; and

- photo of the optic nerve head was taken by the Zeiss FF 450 Plus fundus camera.

Pathologic findings in at least two of these parameters (e.g., visual field changes, excavation of optic disc with the cup/disc (C/D) ratio of 0.3 or greater, IOP of $22 \mathrm{~mm} \mathrm{Hg}$ or greater) meant that the patients were diagnosed with glaucoma.

\section{Statistical analysis}

The data obtained were systematized as variables of nominal type. Correlation between the results of diagnostic procedures and the patient category was tested by comparing $\mathrm{p}$-values applying $\chi^{2}$-test and Fisher exact test, depending on data. The significance level was defined as $\alpha=0.05$. Statistical analysis was done by SAS 9.1 (SAS Institute Inc., Cary, NC, USA).

\section{Results}

Statistical analysis of the patients (applying $\chi^{2}$-test) in the risk groups based on the parameters defining glaucoma showed that distribution of patients with glaucoma was not equal in different risk groups. Comparison of $\mathrm{p}$-values showed that the prevalence of 
Fig. 1. Prevalence of primary open angle glaucoma in particular risk groups.
PERCENTAGE OF PATIENTS IN RISK GROUPS

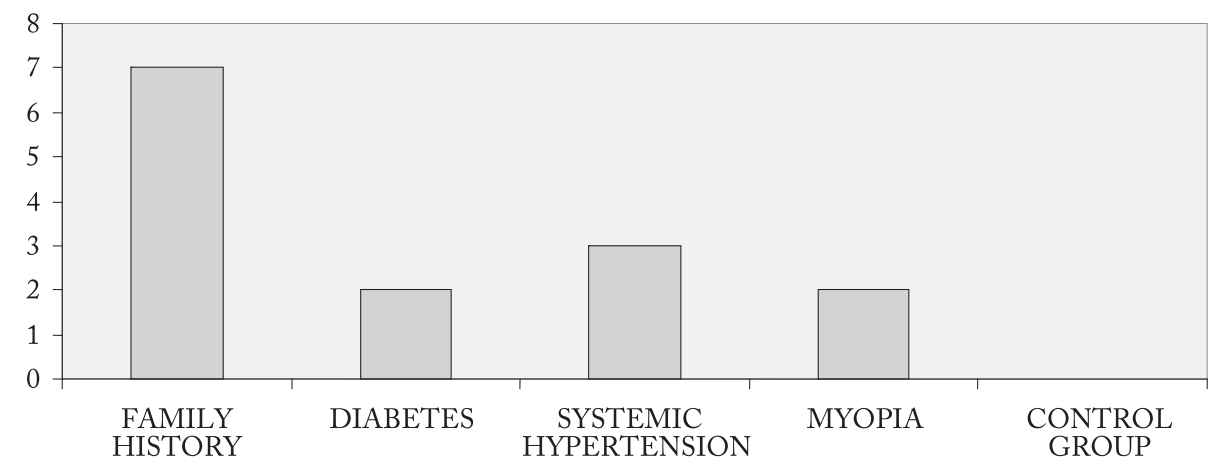

DIABETES

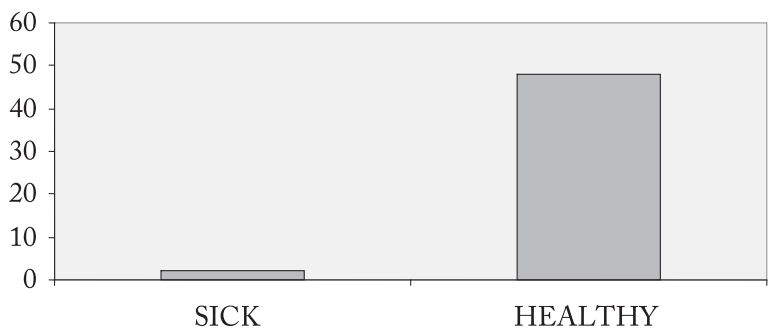

Fig. 2. Prevalence of primary open angle glaucoma in patients with diabetes.

\section{SYSTEMIC HYPERTENSION}

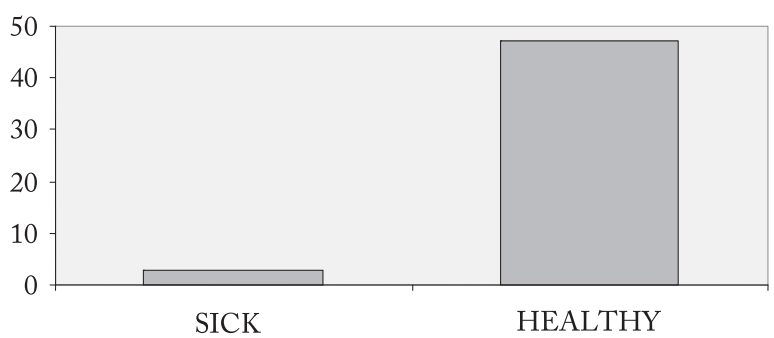

Fig. 3. Prevalence of primary open angle glaucoma in patients with systemic bypertension.

POAG in patients with a family history of primary simplex glaucoma was statistically significantly greater than in the groups of patients with diabetes and myopia, as well as in the control group. The difference was greatest in relation to the control group. There was no statistically significant difference in the prevalence of glaucoma between the groups of patients with a family history and patients with systemic hypertension (Fig. 1).

In patients with diabetes, the prevalence of POAG was $4 \%$, which was not statistically significant in relation to the control group ( $\mathrm{p}=0.078$ vs. defined significance level of $\mathrm{p}<0.05$ ). These results are shown in Figure 2.
FAMILY HISTORY

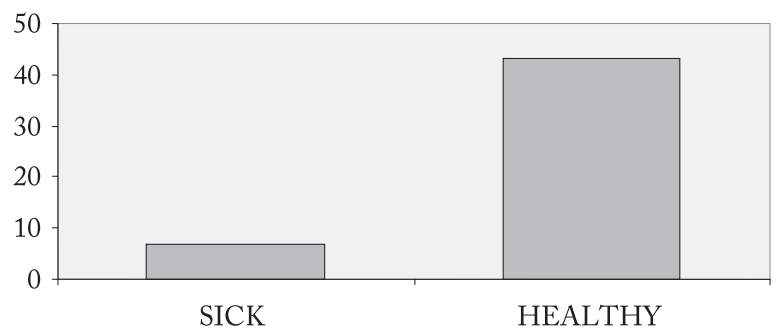

Fig. 4. Prevalence of primary open angle glaucoma in patients with positive family history.

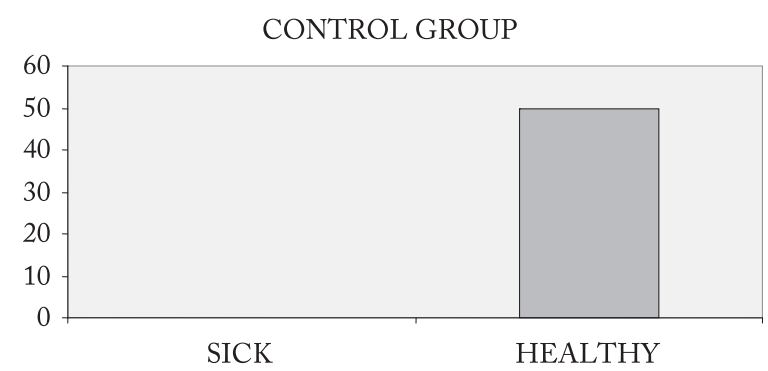

Fig. 5. Prevalence of primary open angle glaucoma in control group.

In patients with systemic hypertension, the POAG prevalence was $6 \%$, which was statistically significant in relation to the control group ( $\mathrm{p}=0.04$, which was less than the defined significance level of $\mathrm{p}<0.05)$. These results are shown in Figure 3.

In patients with a family history, the POAG prevalence was $14 \%$, which was statistically more significant than in the control group ( $\mathrm{p}=0.0036$ in comparison to defined significance level of $\mathrm{p}<0.05$ ), and also statistically more significant than in the groups of patients with myopia and diabetes ( $p=0.04$ in both groups, which was less than defined significance level of $\mathrm{p}<0.05$ ) (Fig. 4). 
The results of this research showed that, based on the set variables, not a single case of POAG was detected in the control group (Fig. 5).

\section{Discussion}

Patients with diabetes are at a moderate risk of developing POAG. The possible pathogenetic sequence is disturbed microcirculation in the optic nerve head and changes of glial and neuronal activity, as well as in metabolism of the retina ${ }^{13}$, which can lead to apoptosis of retinal ganglion cells. Thus, diabetes may cause damage to neuronal metabolism and to retinal glia, which may further result in hypersensitivity of these cells to stress, as well as in the possible increase in IOP. This brings diabetes in direct positive correlation with development of glaucoma damage to the optic nerve.

In diabetic patients included in this research, the prevalence of POAG was $4 \%$, which was not statistically significant in relation to the control group $(\mathrm{p}=0.078$ and $\mathrm{p}<0.05$, respectively). These results are similar to those obtained in the Framingham Eye Study $^{14}$ and Baltimore Study ${ }^{15}$, according to which diabetes and POAG did not show significant correlation. Furthermore, the Collaborative Glaucoma Study also confirmed that there was no significant correlation between diabetes and $\mathrm{POAG}^{16}$. However, in the Rotterdam Study, where the same parameters as in our study were used (visual field damage, $\mathrm{C} / \mathrm{D}$ ratio and IOP greater than $21 \mathrm{~mm} \mathrm{Hg}$ ), the prevalence of developing POAG in patients with diabetes was three times higher than in other studies ${ }^{17}$.

Numerous studies have confirmed the significance of vascular factors and hypertension for development of glaucoma. The Collaborative Normal Tension Glaucoma Study showed that disc hemorrhage in patients with frequent migraine headaches and vasospasms was an important factor contributing to glaucoma progres$\operatorname{sion}^{18}$. Looped/coiled peripapillary blood vessels, peripapillary retinal nerve fiber layer (RNFL) thinning, and arteriolar stenosis are the areas with greatest visual field loss ${ }^{19}$. The Baltimore Study showed that increased systemic pressure may have a protective role only in the initial stage of glaucoma development, whereas in the later stage it stimulates glaucoma progression, mainly because it usually affects elderly people who already suffer from atherosclerosis, which directly disturbs ocular perfusion pressure and blood flow auto- regulation ${ }^{11}$. To preserve hemodynamic balance in the optic disc, it is necessary to maintain blood flow autoregulation, which means that whenever there is an increase in IOP, peripheral vascular resistance decreases or the pressure in the ophthalmic artery increases ${ }^{20-22}$.

Despite the fact that some studies have shown positive correlation between IOP values and systemic blood pressure values, it was not confirmed in a large population study (Baltimore Eye Survey). Some facts are contradictory. Namely, the same study confirmed great and statistically significant correlation between untreated systemic hypertension and glaucoma on the one hand, while on the other hand, the patients treated for hypertension included in the same study were not at a higher risk of developing glaucoma than the control group. It seems logical that increased systemic pressure damages capillary circulation and thus decreases optic disc perfusion, but from the physiological aspect these contradictory facts lead to the conclusion that systemic hypertension represents a low risk for development of glaucoma.

Positive family history of POAG correlates positively with more severe clinical symptoms of POAG, which is defined as increased vertical C/D ratio. However, in some studies, positive family history did not correlate with the degree of visual field damage. Thus, in the study by Landers et al. ${ }^{23}$, it was concluded that positive family history of POAG did not have any influence on the progression of glaucoma. Namely, they confirmed that positive family history of POAG correlated with better results in visual field test in patients under the age of 50, but not in older ones.

In the group of patients with a family history of POAG included in this study, $14 \%$ of patients were first diagnosed with POAG, which was statistically more significant than in the control group ( $\mathrm{p}=0.0036$ and $\mathrm{p}<0.05$, respectively), and also statistically more significant than in the groups of patients with myopia and diabetes. This relatively high of prevalence POAG in the group with positive family history corresponds to the results obtained in other studies, where the prevalence is between $13 \%$ and $25 \%{ }^{24,25}$.

This high percentage leads to the conclusion that positive family history represents the greatest risk factor for development of glaucoma compared to other factors analyzed in all risk groups. It is well known that in one-sixth of all glaucoma cases, there is a positive family history. The risk of glaucoma development is 
almost 10 times higher in first-degree relatives than in control groups ${ }^{26}$. Also, some studies confirmed that the first-degree relatives of patients with POAG had a $42.5 \%$ higher risk of increased IOP than patients in the control group, increased C/D ratio was $62.2 \%$ in comparison to $16.6 \%$ in the control group, and the risk of glaucoma development was $22.0 \%$ in comparison to $2.3 \%$ in the control group ${ }^{26}$. This positive correlation between family history and POAG development may be explained by the fact that two of the variables taken into account for diagnosing glaucoma (IOP and C/D ratio) are genetically determined ${ }^{27}$.

Even though the mechanisms regarding myopia and glaucoma development are still insufficiently explained, it is assumed that the optic nerve head in myopic eyes is structurally more sensitive to glaucoma damage due to structural changes in connective tissue $^{28,29}$. Some studies show that the risk of developing glaucoma is proportional to myopia degree. According to Mitchell et al. in the Blue Mountains Eye Study, the odds ratio for glaucoma development was 2.3 in low myopia and 3.3 in moderate to high myopia ${ }^{30}$. The prevalence of POAG in patients with myopia in our study was $4 \%$, which was not statistically significant in relation to the control group ( $\mathrm{p}=0.0782$ and $\mathrm{p}<0.05$, respectively). Daubs and Crick also confirmed greater prevalence of POAG in patients with myopia ${ }^{31}$.

\section{Conclusion}

Early diagnosis of glaucoma is primarily based on morphological analysis of the optic nerve head, IOP and CCT measurement, as well as on the analysis of visual field progression applying up-to-date functional tests. Histologic studies have confirmed that significant loss of RNFL and optic nerve fibers occurs prior to functional vision field losses measurable by current diagnostics. Unfortunately, technology that could detect the disease in its initial stages does not exist. One of the reasons is certainly the fact that the etiopathology of the disease has not yet been completely explained. This study confirmed the significance of doing early screening in risk groups of patients in order to detect glaucoma as early as possible. Only early diagnosis and timely treatment can prevent development of permanent complications that will result in blindness.

\section{References}

1. Hattenhauer MG, Johnson DH, Ing HH, Herman DC, Hodge DO, Yawn BP, et al. The probability of blindness from openangle glaucoma. Ophthalmology. 1998 Nov;105(11):2099-104. doi: 10.1016/S0161-6420(98)91133-2

2. King AJ, Reddy A, Thompson JR, Rosenthal AR. The rates of blindness and of partial sight registration in glaucoma patients. Eye (Lond). 2000 Aug;14(Pt 4):613-9. doi: 10.1038/ eye. 2000.152

3. O’Brien C. Vasospasm and glaucoma. Br J Ophthalmol. 1998 Aug;82(8):855-6.

4. Gherghel D, Orgul S, Dubler B, Lubeck P, Gugleta K, Flammer J. Is vascular regulation in the central retinal artery altered in persons with vasospasm? Arch Ophthalmol. 1999 Oct; 117(10):1359-62.

5. Mitchell P, Smith W, Chey T, Healey PR. Open-angle glaucoma and diabetes: the Blue Mountains eye study, Australia. Ophthalmology. 1997 Apr;104(4):712-8. doi: 10.1016/S01616420(97)30247-4

6. de Voogd S, Ikram MK, Wolfs RC, Jansonius NM, Witteman JC, Hofman A, et al. Is diabetes mellitus a risk factor for openangle glaucoma? The Rotterdam Study. Ophthalmology. 2006 Oct;113(10):1827-31. doi: S0161-6420(06)00692-0 10.1016/j. ophtha.2006.03.063

7. Flammer J, Pache M, Resink T. Vasospasm, its role in the pathogenesis of diseases with particular reference to the eye. Prog Retin Eye Res. 2001 May;20(3):319-49. doi: S13509462(00)00028-8

8. Xu L, Wang Y, Wang S, Jonas JB. High myopia and glaucoma susceptibility: the Beijing Eye Study. Ophthalmology. 2007 Feb;114(2):216-20. doi: 10.1016/j.ophtha.2006.06.050

9. Jonas JB, Dichtl A. Optic disc morphology in myopic primary open-angle glaucoma. Graefes Arch Clin Exp Ophthalmol. 1997 Oct;235(10):627-33.

10. Mitchell P, Lee AJ, Rochtchina E, Wang JJ. Open-angle glaucoma and systemic hypertension: the Blue Mountains Eye Study. J Glaucoma. 2004 Aug;13(4):319-26. doi: 10.1097/ 00061198-200408000-00010

11. Tielsch JM, Katz J, Sommer A, Quigley HA, Javitt JC. Hypertension, perfusion pressure, and primary open-angle glaucoma. A population-based assessment. Arch Ophthalmol. 1995 Feb; 113(2):216-21.

12. Grodum K, Heijl A, Bengtsson B. Refractive error and glaucoma. Acta Ophthalmol Scand. 2001 Dec;79(6):560-6. doi: 10.1034/j.1600-0420.2001.790603.x

13. Zeng XX, Ng YK, Ling EA. Neuronal and microglial response in the retina of streptozotocin-induced diabetic rats. Vis Neurosci. 2000 May-Jun;17(3):463-71. doi: 10.1017/S09525238 00173122

14. Kahn HA, Milton RC. Alternative definitions of open-angle glaucoma. Effect on prevalence and associations in the Framingham Eye Study. Arch Ophthalmol. 1980 Dec;98(12):2172-7. 
15. Tielsch JM, Katz J, Quigley HA, Javitt JC, Sommer A. Diabetes, intraocular pressure, and primary open-angle glaucoma in the Baltimore Eye Survey. Ophthalmology. 1995 Jan;102(1): 48-53. doi S0161-6420(95)31055-X:

16. Armaly MF, Krueger DE, Maunder L, Becker B, Hetherington $\mathrm{J} J \mathrm{r}$, Kolker AE, et al. Biostatistical analysis of the collaborative glaucoma study. I. Summary report of the risk factors for glaucomatous visual-field defects. Arch Ophthalmol. 1980 Dec; 98(12):2163-71.

17. Dielemans I, de Jong PT, Stolk R, Vingerling JR, Grobbee DE, Hofman A. Primary open-angle glaucoma, intraocular pressure, and diabetes mellitus in the general elderly population. The Rotterdam Study. Ophthalmology. 1996 Aug;103(8): 1271-5. doi: S0161-6420(96)30511-3

18. Drance S, Anderson DR, Schulzer M. Risk factors for progression of visual field abnormalities in normal-tension glaucoma. Am J Ophthalmol. 2001 Jun;131(6):699-708. doi: S0002939 401009643

19. Rader J, Feuer WJ, Anderson DR. Peripapillary vasoconstriction in the glaucomas and the anterior ischemic optic neuropathies. Am J Ophthalmol. 1994 Jan 15;117(1):72-80.

20. Dielemans I, Vingerling JR, Algra D, Hofman A, Grobbee DE, de Jong PT. Primary open-angle glaucoma, intraocular pressure, and systemic blood pressure in the general elderly population. The Rotterdam Study. Ophthalmology. 1995 Jan;102(1):54-60. doi: S0161-6420(95)31054-8 [

21. Leske MC, Connell AM, Wu SY, Nemesure B, Li X, Schachat A, et al. Incidence of open-angle glaucoma: the Barbados Eye Studies. The Barbados Eye Studies Group. Arch Ophthalmol. 2001 Jan;119(1):89-95. doi: eeb90032

22. Bonomi L, Marchini G, Marraffa M, Bernardi P, De Franco I, Perfetti S, et al. Epidemiology of angle-closure glaucoma: prev- alence, clinical types, and association with peripheral anterior chamber depth in the Egna-Neumarket Glaucoma Study. Ophthalmology. 2000 May;107(5):998-1003. doi: S0161642 000000221

23. Landers J, Goldberg I, Graham S. Does a family history of glaucoma affect disease severity at the time of diagnosis? J Glaucoma. 2003 Feb;12(1):31-5.

24. Becker B, Kolker AE, Roth FD. Glaucoma family study. Am J Ophthalmol. 1960 Oct;50:557-67.

25. Kellerman L, Posner A. The value of heredity in the detection and study of glaucoma. Am J Ophthalmol. 1955 Nov;40 (5 Part 1):681-5.

26. Wolfs RC, Klaver CC, Ramrattan RS, van Duijn CM, Hofman A, de Jong PT. Genetic risk of primary open-angle glaucoma. Population-based familial aggregation study. Arch Ophthalmol. 1998 Dec;116(12):1640-5.

27. Armaly MF. Genetic determination of cup/disc ratio of the optic nerve. Arch Ophthalmol. 1967 Jul;78(1):35-43.

28. Cahane M, Bartov E. Axial length and scleral thickness effect on susceptibility to glaucomatous damage: a theoretical model implementing Laplace's law. Ophthalmic Res. 1992;24(5): 280-4.

29. Mitchell P, Hourihan F, Sandbach J, Wang JJ. The relationship between glaucoma and myopia: the Blue Mountains Eye Study. Ophthalmology. 1999 Oct;106(10):2010-5.

30. Curtin BJ, Iwamoto T, Renaldo DP. Normal and staphylomatous sclera of high myopia. An electron microscopic study. Arch Ophthalmol. 1979 May;97(5):912-5.

31. Daubs JG, Crick RP. Effect of refractive error on the risk of ocular hypertension and open angle glaucoma. Trans Ophthalmol Soc U K. 1981;101(1):121-6.

\section{Sažetak}

\section{UČESTALOST GLAUKOMA OTVORENOG KUTA U RIZIČNIM SKUPINAMA U OSJEČKO-BARANJSKOJ ŽUPANIJI}

\section{J. Barać, D. Biuk, S. Matić, I. Barać, G. Pelčić i M. Bradvica}

Cilj ove prospektivne studije bio je dijagnosticirati primarni glaukom otvorenog kuta (POAG) u ranom stadiju kod bolesnika s visokim rizikom od razvoja POAG te identificirati skupinu bolesnika s najvećom učestalošću POAG. Studija je provedena na Zavodu za oftalmologiju Kliničkog bolničkog centra Osijek i uključila je 250 bolesnika podijeljenih u pet skupina: skupina 1: bolesnici s dijabetes melitusom tip 1 i 2; skupina 2: bolesnici s arterijskom hipertenzijom (krvni tlak $>140 / 90 \mathrm{~mm} \mathrm{Hg}$ ); skupina 3: bolesnici s pozitivnom obiteljskom anamnezom POAG; skupina 4: bolesnici s miopijom između -3 i -8 dioptrije sfere; skupina 5: kontrolna skupina koja uključuje bolesnike starije od 40 godina i bez rizičnih čimbenika za razvoj POAG. Rezultati studije pokazuju da distribucija bolesnika s glaukomom nije jednaka u svim skupinama. Učestalost POAG u svih bolesnika bila je 5,6\%, dok je u bolesnika s pozitivnom obiteljskom anamnezom bila 14\%, što je statistički zančajno više nego u bolesnika s dijabetesom i miopijom (4\%) i u kontrolnoj skupini. Razlika je bila najveća u usporedbi s kontrolnom skupinom. Nije pronađena statistički značajna razlika u učestalosti POAG između bolesnika s pozitivnom obiteljskom anamnezom (14\%) i bolesnika s arterijskom hipertenzijom (6\%). Dobiveni rezultati navode na zaključak da je za pojavu POAG od svih analiziranih rizičnih čimbenika najvažnija pozitivna obiteljska anamneza.

Ključne riječi: Prospektiona istraživanja; Glaukom otvorenog kuta; Hipertenzija; Miopija; Glaukom; Rizični cimbenici; Kontrolne skupine 